\title{
IAMJ
}

INTERNATIONAL

AYURVEDIC

MEDICAL JOURNAL

\section{NIDAN PANCHAKA WITH SPECIAL REFERENCE TO VISHAMAJWARA - A LITERARY REVIEW}

\author{
Shivam Kumar Nigam ${ }^{1}$, Rita Singh², Sanjay Srivastava ${ }^{3}$ \\ ${ }^{1}$ PG Scholar, Rog Nidan \& Vikriti Vigyan \\ ${ }^{2}$ Reader, Rog Nidan \& Vikriti Vigyan \\ ${ }^{3}$ Professor and HOD, Rog Nidan \&Vikriti Vigyan \\ Pt. Khusilal Sharma Government (Autonomous) Ayurveda Institute, Bhopal, Madhya Pradesh, India
}

Corresponding Author: nigamshivam143@gmail.com

\section{https://doi.org/10.46607/iamj1709062021}

(Published Online: June 2021)

Open Access

(C) International Ayurvedic Medical Journal, India 2021

Article Received: 29/05/2021 - Peer Reviewed: 09/06/2021 - Accepted for Publication: 10/06/2021

\section{Check for updates}

\section{ABSTRACT \\ Nidan Panchaka is an important tool of diagnosis. Its five subtypes are Nidan, Poorvaroopa, Roopa, Samprapti and Upshaya. It is an important aspect to diagnose a disease and its stages. Nidan Panchaka not only gives the knowledge of diagnosis but also gives knowledge about prognosis, complications and differential diagnosis. $V i$ - shamajwara is a type of fever that is characterized by its irregularity. It has five subtypes. It is a very crucial dis- ease, and its features are like many diseases like Malaria, typhoid etc. Nidan Panchaka of Vishamajwara is scat- tered and not mentioned clearly in any Samhita. Here an attempt has been made to understand the Nidan Pancha- $k a$ of Vishamajwara.}

Keywords: Nidan, Poorvaroopa, Roopa, Samprapti, Upshaya, Vishamajwara

\section{INTRODUCTION}

Appropriate diagnosis of a disease is a key to its successful management. It is a base for proper treatment whereas ignorance of disease or improper diagnosis leads to hazardous conditions for patients or physi- 
cians. So, the diagnosis of the disease comes first and foremost as advocated by Acharya Charaka too; Rogam aadoo parikshyate tato anantarm auoshdham ${ }^{l}$ Means a physician should examine the disease thoroughly before prescribing medicine. In Ayurveda Rogi Pariksha and Rog Pariksha is a basic tool for the diagnostic approach of disease. For Rogi Pariksha Trividha, Shadvidha, Ashtavidha etc. Pariksha are described in the classics and for Rog Pariksha Nidan Panchaka is described which includes Nidan, Poorvaroopa, Rupa, Upashaya and Samprapti.Roga Pariksha gives complete knowledge of the disease manifestation like its etiology, prodromal symptoms, pathogenesis, prognosis, treatment, and differential diagnosis of the disease. Nidanam poorvaroopani rupani upshayasthatha. Sampraptishcha iti vigyanam roganaam panchdha smritam. ${ }^{2}$ Each of these helps a physician for a better understanding of the disease process, making an accurate diagnosis, and selection of the best treatment. With the use of Nidan Panchaka, a physician can diagnose the disease at an earlier stage and plan for the appropriate treatment well and also further complication is prevented. Every disease including Jwara has its aetiology, symptoms, pathogenesis, and explorative therapy means it has its own $\mathrm{Ni}$ dan Panchaka. All living beings are born or die with Jwara. No other disease is powerful than Jwara. It is considered the king of all diseases because it associates with many diseases. ${ }^{3}$ Jwara is not only a disease; it is a state where the body, mind as well as sense organs suffer due to the raised temperature. The individual succumbs to death after suffering from some kinds of fever like typhoid, plague, malaria, chikungunya virus, etc. According to Acharya Sushruta, the disease is marked by the obstructed secretion of perspiration by sweat glands, or increased temperature, or pain all over the body with a sense of numbness in the limbs, is called Jwara (fever). ${ }^{4}$ There are several types of Jwara mentioned in classic, one of them is $\mathrm{Vi}$ shamaJwara. VishamaJwara is irregular in its onset, action, production of symptoms, time of appearance, and persistence for long periods. In Samhita Granthas wide description of Vishama jwara is available. According to Kashyapa, in the Vishamajwara specific properties of Jwara are found in an irregularly manner. ${ }^{5}$ It depends upon Vegavastha and Avegavastha. Bhaluki define Vishama jwara as that the Jwara which comes with cold or hot stage with temperature rise or low is uncertain. ${ }^{6}$ According to the strengths and weakness of Dosha Vishama jwara divided into five types - i. Santata ii. Satata iii. Anyedushka iv. Triteeyaka v. Chaturthaka. ${ }^{7}$ Vagbhata described the relationship between Rasadi Dhatu and the types of Vishama jwara. All types of Vishama jwara show their effect after involving Rasa, Rakta, Mamsa, Meda, Asthi, and Majja Dhatu and get a place at Shira, Kantha, Hridaya, Amashaya, and Rasavaha Srotas. Scripture related to Vishama jwara is scattered and Nidan Panchaka of Vishama jwara is not available at one place. Here attempt is made to describe $\mathrm{Ni}$ dan Panchaka of Vishama jwara to understand Nidan Panchaka and its role in disease management.

AIM AND OBJECTIVES: To understand the concept of Nidan Panchaka in Vishama Jwara.

\section{MATERIAL AND METHOD:}

Material has been collected from ancient Ayurvedic texts, research journals, and electronic databases.

\section{NIDAN -}

Etiological agent of any disease is called Nidan. Nidan word is considered in two ways i.e., as a diagnostic factor or as a causative factor. In the Nidan Panchaka, it is defined as the causative factor. In Nidan Pancha$k a$ a factor that is capable of manifesting the development of disease either quickly or after a certain period is called Hetu. ${ }^{8}$ According to Acharya Sushrut, 'Sankshepataha Kriya Yogo Nidana Parivarjanam. ${ }^{9}$ This means avoiding the causative factors is the primary and shortest form of treatment. Nidan is responsible for the causation of disease and the further pathogenesis of the disease. Nidan is the first step of disease formation which comes under Sanchaya in Shat Kriyakala. Every disease has its Nidanatamak Hetu. In the classics, the Hetu of Vishamajwara is well described by various Acharyas. Charaka stated that in origin all the Vishama jwara are Tridoshaja. ${ }^{10}$ Also,Sushruta stated, that the Vishama Jwara occurs due to Tridosha and Vata is the dominant Dosha but Agantuka Karana or Parahetu is the main cause of 
Vishama jwara.$^{11}$ As Bhutabhishanga, Dalhana throws light on this Parahetu. In Astanga Hridhaya, Vagbhat mentions role of Mandagni during Adanakala as an important or main aetiology of the manifestation of Vishama jwara. He also advocated if an emaciated patient who takes an irregular diet during the convalescent period despite residual of a small quantity of Dosha may cause Vishama jwara. ${ }^{12}$

POORVAROOPA: Bhavi vyadhi bodhkamev lingam poorvaroopam. ${ }^{13}$ The symptoms which indicate the forthcoming disease is called Poorvaroopa. In other word the weak symptoms which arrive before the disease is known as Poorvaroopa. In the Samprapti of disease according to Kriyakala, it is appearing in Sthansanshrya Awastha. In Poorvaroopa we find the clue or hints about the disease. Poorvaroopa is two types, first is the Samanya Poorvaroopa that gives the clue of disease without giving information of Dosha derangement and second is Vishishta Poorvaroopa which gives an idea about Dosha derangement. Poorvaroopa helps to get knowledge of the Dosha responsible for that disease but not clear about the upcoming disease. ${ }^{14}$

In the case of Vishama jwara, no specific prodromal sign is described but it is a variety of Jwara so the prodromal symptoms of Jwara are applicable on $\mathrm{Vi}$ shamajwara too. Samanya Poorvaroopa of Jwara are fatigue, weakness, faded skin colour, absence of taste in the mouth, lacrimation, liking or disliking of cold, wind, and sun alternatively, yawning, malaise, heaviness, horripilation, laziness, absence of pleasure, feeling of cold, etc..$^{15}$ Vishishta Poorvaroopa of Jwara is excessive yawning occurs before Vataja jwar, in Pitaja Jwara burning sensation in the eyes and in the Kaphaja Jwara dislike for food is occurring. ${ }^{16}$

ROOPA: It is the confirmatory sign of disease. Utpannavyadhibodhakamev lingarupam.${ }^{17}$ Roopa indicates the specific disease by manifesting specific symptoms of that disease. It appears in Vyaktawastha when the Dosh Dushya Sammurchhana is completed. 1. The Roopa of the disease are always seen after the aggravation and formation of disease. Roopa Awastha 2. helps in planning specific Vyadhi Pratyanik Chikitsa of disease. ${ }^{18}$ When the Roopa appears, the disease become more understandable.

Jwara affects the whole body, organs, system, and mind. Vishama jwara is characterized by Vishamarambha (irregular onset), Vishamkriya (irregular kriya of hot and cold), Vishamkala (irregular duration of suffering). ${ }^{19}$ Vishama jwara is classified into five types. Each has its special features. They are Santata, Satata, Anyedushka, Triteeyak and Chaturthaka. A feature of Santata Jwara-Rasa Dhatu is the main site of Santata Jwara and continuous fever is its main feature. According to Vata, Pitta, Kapha, Dosha's involvement is for 7 days, 10 days and 12 days respectively. In this period without therapeutic intervention, it may either get cure or kills the person. ${ }^{20}$

Features of Satata Jwara: In Satata Jwara Dosha moves from Rasvaha Srotas to Raktavaha Srotas. Raktavaha Srotas is comparatively more distant than Rasavaha Srotas. So Dosha gets a long time to enter in Raktavaha Srotas which is the prime seat of $\mathrm{Vi}$ shama jwara. According to Kashyapa,this type of aggravation and remission depends upon the Kala, Dosha,and Dushyas. ${ }^{21}$ It is a Dwikalika (two times) Jwara which comes two times in Ahoratra (24 hours). ${ }^{22}$ The vitiated Dosha are localized in Raktavaha Srotas and aggravated once in day and once at night.

Features of Anyedushka Jwara: In Anyedushka Jwara symptoms appear once in whole day or night. Because Dosha circulated all over the body and takes place in Mansavaha Srotas. ${ }^{23}$ It is quite far from Raktavaha Srotas so it reaches late in Mansavaha Srotas due to this delay Vega comes once in whole day or night.

Features of Triteeyak Jwara ${ }^{24}$ : In Triteeyak Jwara fever comes on first day and recurred in every third day. Vagbhata considered that the sites of vitiated Dosha localized are Meda dhatu and Medovaha Srotas. According to Dosh Dushya, Triteeyaka Jwara have three sub types,

Due to Kapha and Pitta involvement pain starts from the Trika region

Due to Vata and Kapha involvement pain starts from the back 
3. Due to Vata and Pitta involvement pain starts from the head.

Features of Chaturthaka Jwara ${ }^{25}$ : Jwaravega comes after the gap of two days. The site of Dosha in this Jwara is said to be Majja-Dhat, which is deeper than Rasavaha and other Srotas. Hence vitiated Dosha takes a longer period to reach there. Therefore, fever occurs on every fourth day. It has been classified into two types.

Kaphadhikya Chaturthak Jwara originates from Jangha Pradesh and spread all over the body and Vatadhikya Chaturtaka Jwara originates from Shira and spread throughout the body.

SAMPRAPTI: Samprapti means pathogenesis of disease.

Vyadhijanak doshavyapar vishesyuktamvyadhijanmeh sampraptiah $^{26}$

The disease manifests due to the specific action of the Dosha and understanding of such events is called Samprapti. The complete disease process which begins from Nidan Sevan to appearing of Roopa is called Samprapti. There are two types of Samprapti i.e. Samanya Samprapti and Vishista Samprapti. ${ }^{27}$ In Samanya Samprapti, Shatkriyakala of any disease is described. In Vishista types of Samprapti i.e Sankhya, Pradhanya, Vidhi, Vikalpa, Bala, Kala Samprapti are included. All these factors help the Vighatana of Samprapti and help diagnose the contributory factors of the disease.

In the process of Samprapti due to consumption of various Aaharaja, Viharaja and other types of Nidan Dosha got vitiated. These vitiated Dosha moves in various directions in the body with the help of Rogamarga. Depending upon the cause or type of vitiation and direction or route followed by the vitiated Dosha get a place on the defective site produced due to phenomena of kha-Vaigunya and Dosha-Dushya Sammurchchhana occur which produces disease. ${ }^{28}$

Due to Mithya Ahara Vihara taken in case of residual fever and on other hand due to Agantuja Nidan (Jeevanu) may aggravate Vata Dosha localized in Kaphasthana (Shira, Kantha, Hridaya, Amashaya) it leads to Raktadi Dhatu dushti which aggravate all the three Dosha and Mala vruddhi, both Mala vriddhi and
Dosha prokopa leads to Ojo Kshya. It produces $\mathrm{Vi}$ shama Jwara being localized in one or more Dhatu. ${ }^{29}$, 30

UPASHAYA: Sukhavahamiti sukham roganivritii lakshanam $^{31}$

The word pleasure is used in context to Upshaya, means which gives happiness and pacifies the disease. Due to some latent or mimicking nature of the disease Upshaya \& Anupashaya helps to diagnose the disease in such circumstances. ${ }^{32}$ It is strenuous to identify or diagnose a disease due to its unclear manifestation. Relieving and aggravating factors help in making the correct diagnosis. Chakrapani described 18 subtypes of Upshaya. In the case of Vishama jwara for each type different types of Kashaya is prescribed. Clarified butter duly cooked with the decoction of Kola, Agnimantha and Triphala with milk-curd (Dadhi) and with Tilvaka as Kalka would be found to be highly efficacious in a case of Vishama jwara. In the treatment of Vishama jwara more emphasis is laid on bitter drugs like Kirata, Guduchi, Bharangi, Nimba etc. Purgatives and emetics should be avoided. ${ }^{33}$

\section{DISCUSSION}

The physician, who knows the proper diagnosis technique, succeeds every time in the treatment. These five elements of Nidan Panchaka help in making an accurate diagnosis. By knowing the Nidana Pancha$k a$, physicians can diagnose the disease at an earlier stage and not only plan treatment but prevents further complication also. It is a tool for diagnosis disease at starting to end level. The naming of disease is not given that much importance, but knowing the definite etiological factors, Dosha vitiation, pathogenesis, or progress of disease and checking it at early stage is given prime importance. The first knowledge of Hetu is important to avoid the occurrence of disease because the basic principle of treatment is Nidan Parivarjan so it is necessary in Vishama Jwara must avoid Nidan like a heavy meal, unsuitable diet, Apathayapalan etc. In the second factor Poorvaroopa, help to cure incompletely manifested disease in its early stage because it requires minimal or simpler modalities of treatment. The Poorvaroopa of Jwara is considered 
its Poorvaroopa as no specific Poorvaroopa of Visama Jwara is given. In the Roopa stage, pathogenesis of the disease is completed, and symptoms of the disease were showed which is helpful for the planning of specific treatment. In Vishama jwara there are five subtypes i.e., Santata, Satata, Anyedushka, Triteeyak, and Chaturthaka Jwara. All have their specific features and pattern of fever. Knowledge of Roopa of every Vishama jwara is helpful for differential diagnosis and specific kind of treatment for each. The Samprapti, gives complete knowledge of disease and Samprapti Ghatak which are responsible for its pathogenesis are beneficial for treatment purpose. Samprapti also gives knowledge about route of the disease, involved Dhatus and affected Srotas. In the Samprapti of Vishama Jwara, Aagantuja Nidana and Mithya Ahara Vihara have taken in case of residual fever plays a vital role. Upashaya plays an important role in the hidden point of diagnosis, differential diagnosis, and treatment of disease. In Vishama jwara bitter drugs like Kirat, Guduchi, Bharangi, Nimba etc. are useful and Purgatives and emetics should be avoided. Each component of Nidana Panchaka individually helps to make a correct diagnosis. If one component indicates a disease, then other aspects of Nidana Panchaka confirm the diagnosis. This applies to Vishama jwara too. A good diagnosis is a basis of good treatment which gives fame and trust to a physician.

\section{CONCLUSION}

A proper diagnosis is essential before giving any kind of treatment. By knowing the Nidan Panchaka, physician achieves confirmation of disease and gives the better treatment to patients. Nidan Panchaka is the best method for the diagnosis of a disease. Going through various kinds of literatures available, Nidan Panchaka of Vishama jwara has been explored. The physician, who diagnoses the disease and treats according to Nidan Panchaka, will become a successful practitioner.

\section{REFERENCES}

1. Kashinatha Sastri, Gorakha Natha Chaturvedi;Charak Samhita Of Agnivesha,Vol I, Maharoga Adhyaya 20/20. Chaukhamba Bharati Academy: Varanasi;.Reprint Edition 2017,P-406

2. Upadhyaya Yadunandan, Astanga Hridaya Vagbhatta With Vidyottini Tika Of Atridev Gupta, Nidana Stan, Sarvarognidanadhyaya 1/2, Chaukhambha Prakashan; Varanasi, Reprinted Edition 2017, P-294.

3. Shastri A. Sushruta Samhita Of Maharsi Sushruta With Ayurveda Tattva Sandipika Commentary,Part Ii,Uttar Tantra, Jvara Pratishedha 39/10, Chaukhamba Sanskrit Sansthan: Varanasi; 2014,P-213

4. Shastri A. Sushruta Samhita Of Maharsi Sushruta With Ayurveda Tattva Sandipika Commentary,Part Ii,Uttar Tantra, Jvara Pratishedha 39/13, Chaukhamba Sanskrit Sansthan: Varanasi; 2014,P-213.

5. Saurabh Parauha, M.A. Hullur, A.S.Prashanth; A Litreary Review Of Vishama Jwara And Its Principle Of Treatment; Journal Of Ayurveda And Integrated Medical Sciences , July - Aug 2016,Vol. 1, Issue 2

6. Tripathi Brahmananda,Madhava Nidanam Roga Viniscaya Of Sri Madhavakara With The Sanskrit Commentary Madhukosa By Vijayaraksita \&Srikanthadatta, Vol.I, Chappter2/31, Chaukhamba Surbharati Prakashan, Varanasi, Reprint Edition 2014,P-128

7. Shukla Vidyadhar,Tripathi Ravidutta;Charak Samhita Of Agnivesha With Vidyamanorama Hindi Commentary,Vol.Ii Jwara Adhyaya,03/34 Chaukhamba Sanskrit Pratishthan,Varanasi; Reprint Edition 2014,P-73

8. Byadgi S.Parameswarappa, Text Book Of Vikrti Vijnana \& Roga Vijnana,Vol.I, Chapter5.3,Chaukhmbha Publications ,New Delhi, Reprint Edition 2019 P-397

9. Shastri A. Sushruta Samhita Of Maharsi Sushruta With Ayurveda Tattva Sandipika Commentary,Part Ii,Aupadravika Adhyayam 01/25 Chaukhamba Sanskrit Sansthan: Varanasi; 2014,P-14

10. Shukla Vidyadhar,Tripathi Ravidutta;Charak Samhita Of Agnivesha With Vidyamanorama Hindi Commentary,Vol.Ii Jwara Adhyaya,03/74, Chaukhamba Sanskrit Pratishthan,Varanasi; Reprint Edition 2014,P-80

11. Shastri A. Sushruta Samhita Of Maharsi Sushruta With Ayurveda Tattva Sandipika Commentary,Part ,Part Ii,Uttar Tantra, Jvara Pratishedha 39/56, Chaukhamba Sanskrit Sansthan: Varanasi; 2014,P-228..

12. Upadhyaya Yadunandan, Astanga Hridaya Vagbhatta With Vidyottini Tika Of Atridev Gupta, Nidana Stan, 
Jwaranidanadhyaya 2/64, Chaukhambha Prakashan; Varanasi, Reprinted Edition 2017, P-305.

13. Tripathi Brahmananda,Madhava Nidanam Roga Viniscaya Of Sri Madhavakara With The Sanskrit Commentary Madhukosa By Vijayaraksita \&Srikanthadatta, Vol.I, Chappter1/5-6chaukhamba Surbharati Prakashan, Varanasi, Reprint Edition 2014,P-33

14. Sharma Ravikant, Bairwa Charan Singh, Sapra Umesh Kumar, Gujjarwar Vidula; Clinical Importance Of Nidana Panchaka - A Review; Iamj,February 2019; Volume 7; Issue 2

15. Shukla Vidyadhar,Tripathi Ravidutta;Charak Samhita Of Agnivesha With Vidyamanorama Hindi Commentary,Vol.Ii Jwara Adhyaya, 03/28-29chaukhamba Sanskrit Pratishthan,Varanasi; Reprint Edition 2014,P-73

16. Shastri A. Sushruta Samhita Of Maharsi Sushruta With Ayurveda Tattva Sandipika Commentary,Part ,Part Ii,Uttar Tantra, Jvara Pratishedha 39/27, Chaukhamba Sanskrit Sansthan: Varanasi; 2014,P-220.

17. Tripathi Brahmananda,Madhava Nidanam Roga Viniscaya Of Sri Madhavakara With The Sanskrit Commentary Madhukosa By Vijayaraksita \&Srikanthadatta, Vol.I, Chappter1/7, Chaukhamba Surbharati Prakashan: Varanasi; Reprint Edition 2014,P-40

18. Byadgi S.Parameswarappa, Text Book Of Vikrti Vijnana \& Roga Vijnana,Vol.I, Chapter 5.2,Chaukhmbha Publications ,New Delhi, Reprint Edition 2019,P-394

19. Athavale AD, Astanga Sangraha With Indu vyakhya, 2008, Nidan Stana, 02/69.

20. Shukla Vidyadhar,Tripathi Ravidutta;Charak Samhita Of Agnivesha With Vidyamanorama Hindi Commentary,Vol.Ii Jwara Adhyaya,03/54-55, Chaukhamba Sanskrit Pratishthan,Varanasi; Reprint Edition 2014,P-76

21. Saurabh Parauha, M.A. Hullur, A.S.Prashanth; $A$ Litreary Review Of Vishama Jwara And Its Principle Of Treatment; Journal Of Ayurveda And Integrated Medical Sciences , July - Aug 2016,Vol. 1, Issue 2

22. Shukla Vidyadhar,Tripathi Ravidutta;Charak Samhita Of Agnivesha With Vidyamanorama Hindi Commentary,Vol.Ii Jwara Adhyaya,03/61-62,Chaukhamba Sanskrit Pratishthan,Varanasi; Reprint Edition 2014,P-77

23. Upadhyaya Yadunandan, Astanga Hridaya Vagbhatta With Vidyottini Tika Of Atridev Gupta, Nidana Stan, Jwaranidanadhyaya 2/69, Chaukhambha Prakashan; Varanasi, Reprinted Edition 2017,P-307.

24. Upadhyaya Yadunandan, Astanga Hridaya Vagbhatta With Vidyottini Tika Of Atridev Gupta, Nidana Stan,
Jwaranidanadhyaya 2/70-71, Chaukhambha Prakashan; Varanasi, Reprinted Edition 2017, P-307.

25. Upadhyaya Yadunandan, Astanga Hridaya Vagbhatta With Vidyottini Tika Of Atridev Gupta, Nidana Stan, Jwaranidanadhyaya 2/72, Chaukhambha Prakashan; Varanasi, Reprinted Edition 2017,P-307.

26. Byadgi S.Parameswarappa, Text Book Of Vikrti Vijnana \& Roga Vijnana,Vol.I, Chapter,5.7, Chaukhmbha Publications ,New Delhi, Reprint Edition 2019,P-437

27. Sharma Ravikant, Bairwa Charan Singh, Sapra Umesh Kumar, Gujjarwar Vidula; Clinical Importance Of Nidana Panchaka - A Review; Iamj,February 2019; Volume 7; Issue 2

28. Sharma Ravikant, Bairwa Charan Singh, Sapra Umesh Kumar, Gujjarwar Vidula; Clinical Importance Of Nidana Panchaka - A Review; Iamj,February 2019; Volume 7; Issue 2

29. Shastri A. Sushruta Samhita Of Maharsi Sushruta With Ayurveda Tattva Sandipika Commentary,Part Ii,Uttar Tantra, Jvara Pratishedha 39/ 51chaukhamba Sanskrit Sansthan: Varanasi; 2014,P-224

30. Tripathi Brahmananda,Madhava Nidanam Roga Viniscaya Of Sri Madhavakara With The Sanskrit Commentary Madhukosa By Vijayaraksita \&Srikanthadatta, Vol.I, Chappter2/31, Chaukhamba Surbharati Prakashan, Varanasi, Reprint Edition 2014,P-129

31. Tripathi Brahmananda,Madhava Nidanam Roga Viniscaya Of Sri Madhavakara With The Sanskrit Commentary Madhukosa By Vijayaraksita \&Srikanthadatta, Vol.I, Chappter1/9 Chaukhamba Surbharati Prakashan, Varanasi, Reprint Edition 2014,P-57

32. Byadgi S.Parameswarappa, Text Book Of Vikrti Vijnana \& Roga Vijnana,Vol.I, Chapter5.6, Chaukhmbha Publications ,New Delhi, Reprint Edition 2019 P-430

33. Khot Jitendra, Tarapure Shruti, Jain Pranjal; Ayurvedic Classical Appraisal on Vishamajwara- A Review Article; Paripex - Indian Journal Of Research; | September - 2020; Volume - 9; Issue - 9

\section{Source of Support: Nil \\ Conflict of Interest: None Declared}

How to cite this URL: Shivam Kumar Nigam et al: Nidan Panchaka With Special Reference To Vishamajwara - A Literary Re-View. International Ayurvedic Medical Journal \{online\} 2021 \{cited June, 2021\} Available from: http://www.iamj.in/posts/images/upload/1254_1259.pdf 